\title{
Effect of Organic Manure in the Induction of Resistance of Citrus to Phytophthora parasitica
}

\author{
Luciana Faldoni ${ }^{1,2}$, Mariângela Cristofani-Yaly ${ }^{1}$, Leonardo Pires Boava ${ }^{1}$, Evandro Henrique Schinor ${ }^{1}$ \\ \& Kátia Cristina Kupper ${ }^{1,2}$ \\ ${ }^{1}$ Centro APTA Citros Sylvio Moreira, Cordeirópolis-SP., Brazil \\ ${ }^{2}$ Universidade Federal de São Carlos, Araras-SP, Brazil \\ Correspondence: Kátia Cristina Kupper, Centro APTA Citros Sylvio Moreira, CEP 13490-970, \\ Cordeirópolis-SP., Brazil. E-mail: katia@centrodecitricultura.br
}

Received: December 1, 2014 Accepted: February 10, 2015 Online Published: March 15, 2015

doi:10.5539/jas.v7n4p135 URL: http://dx.doi.org/10.5539/jas.v7n4p135

\begin{abstract}
Gummosis and root rot caused by Phytophthora are among the most economically important diseases in Citrus. Chemical control has been used; however, it is essential to search for new alternatives for its control. This study aimed to: (i) produce an organic compound from the anaerobic fermentation of cattle manure, (ii) determine the microbial diversity present in the compound, (iii) determine the effect of compound on mycelial growth of Phytophthora parasitica (P. nicotianae), (iv) evaluate its effect in inducing resistance to the pathogen in five Citrus rootstocks and, (v) evaluate the expression profile of some defense-related genes in resistant plants of Poncirus trifoliata and susceptible plants of Caipira sweet orange. The largest microbial population occurred between 25 and 35 days after production of organic manure with predominance of Bacillus spp. The organic manure at concentration of $20 \%$ inhibited about $80 \%$ of the mycelial growth of P. parasitica. Plants of Caipira sweet orange (susceptible to $P$. parasitica) when treated with organic manure at all concentrations $(10,20$ and $50 \%$ ), had lower disease severity when compared with the respective control. The analysis of gene expression suggested that the combination of treatment followed by inoculation with the pathogen in plants of Caipira sweet orange, the susceptible genotype, was able to increase the expression level of the genes encoding chitinase (CHI), lipoxygenase $(L O X)$, peroxidase $(P O X), \beta-1,3$-glucanase and chalcone synthase $(C H S)$. It is believed that they should be involved with the resistance of Citrus plants to P. parasitica.
\end{abstract}

Keywords: gummosis, root rot, gene expression, rootstock

\section{Introduction}

Among the problems faced by the Brazilian citriculture, gummosis and root rot caused mainly by Phytophthora parasitica Dastur (= P. nicotianae Breda de Haan var. parasitica (Dastur) Waterhouse) are among the most economically important diseases in Citrus, occurring in nearly all producing regions (Leoni \& Ghini, 2006).

The oomycete infects the main scaffold branches, leading to canker development and gum exudation, lesion spreads upward, affecting secondary branches, and downward, affecting the trunk and roots (Alvarez et al., 2009). Chemicals, such as metalaxyl (a systemic benzenoid fungicide) and fosetyl Al (aluminium ethylhydrogenphosphonate) have been successfully used to control both gummosis and root rot. However, they are not always desirable due to the high costs of application, potential hazards to the environment, and the development of fungicide-resistant strains. Selection and breeding for resistance to Phytophthora in Citrus species is considered the most efficient approach to control the disease, since there are varying degrees of resistance within the genus Citrus and its relatives (Boava et al., 2011).

An alternative approach to control plant diseases is the application of aqueous extracts of organic matter and biofertilizers. The advantages of using organic matter and biofertilizers are the low cost and easy availability of the product, since the farmer can produce it using the available organic material. It can provide solutions to both objectives of safe waste management and sustainable agriculture by converting all the societal waste organics into nutritive organic manure which can be used by farmers to grow more food for society (Sinha et al., 2010).

Induced resistance has been demonstrated in many plant species, and numerous studies have evaluated the expression of defence responses against several important causal agents of plant diseases (Jiang et al., 2008). 
Induced resistance is triggered by the activation of genes that encode a series of pathogenesis-related (PR) proteins which include protein families of varied characteristics, such as chitinases $(\mathrm{CHI}), \beta-1,3$-glucanases $(G L U)$, lysozymes, peroxidases $(P O X)$, besides enzymes involved in lignin and phytoalexin synthesis. A key gene in the route of the biosynthesis of, phytoalexins is Chalcone synthase (CHS). All the above mentioned genes are related to defense processes during pathogenesis (Van Loon et al., 2006).

Given this scenario, this study aimed to: (i) produce an organic compound from the anaerobic fermentation of cattle manure, (ii) determine the microbial diversity present in the organic manure, (iii) determine the effect of the prepared manure on mycelial growth of $P$. parasitica, (iv) evaluate its effect in inducing resistance to $P$. parasitica in five Citrus rootstocks and (v) evaluate the expression profile of some defense-related genes in resistant plants of Poncirus trifoliata and susceptible plants of Caipira sweet orange.

\section{Materials and Methods}

\subsection{Preparation of Organic Manure}

The organic manure was produced according to Kupper et al. (2006), using cattle manure supplemented with macro and micronutrients to stimulate the fermentation $\left(6.5 \mathrm{~g} / \mathrm{L}\right.$ of N; $0.68 \mathrm{~g} / \mathrm{L}$ of $\mathrm{P}_{2} \mathrm{O}_{5} ; 2.5 \mathrm{~g} / \mathrm{L}$ of $\mathrm{K}_{2} \mathrm{O} ; 0.975 \mathrm{~g} / \mathrm{L}$ of Ca; $0.66 \mathrm{~g} / \mathrm{L}$ of Mg; $4.75 \mathrm{~g} / \mathrm{L}$ of S; $1.8 \mathrm{~g} / \mathrm{L}$ of Fe; $0.49 \mathrm{~g} / \mathrm{L}$ of Mn; $0.29 \mathrm{~g} / \mathrm{L}$ of Cu; $2.9 \mathrm{~g} / \mathrm{L}$ of Zn; $0.35 \mathrm{~g} / \mathrm{L}$ of B; $1.20 \mathrm{~g} / \mathrm{L}$ of Na), $6 \mathrm{~L}$ of cattle manure, $2 \mathrm{~L}$ of sugarcane bagasse and water in the ratio of $50 \%(\mathrm{v} / \mathrm{v})$ in a closed plastic recipient completed to a $20 \mathrm{~L}$ volume with water, under anaerobic conditions for a period determined by microbiological analysis.

\subsection{Determination of Culturable Microbial Community in the Organic Manure}

The microbial community composition was determined in filtered samples of the organic manure, diluted up to $10^{-4}$ taken every five days for 60 days. After homogenizing, $100 \mu \mathrm{L}$ of each dilution were spread over the surface of an agar medium in Petri dishes, with a Drigalski loop and the incubation of cultures took place on B.O.D incubator at temperature of $25 \pm 2{ }^{\circ} \mathrm{C}$ in the dark. It was used different culture media to verify the microbial community: a) Martin's medium, to count the total population of fungal colonies; b) Nutrient Agar (NA) for determining the number of bacterial colony-forming units and; c) Potato Dextrose Agar (PDA) for the determination of the colonies of Bacillus spp., an aliquot of the organic manure sample was heat treated at $80^{\circ} \mathrm{C} / 10 \mathrm{~min}$ and the plated on the medium (PDA) (Kupper et al., 2006). Three plates were used for each dilution. The evaluation was performed daily and we proceeded counting and isolation of morphologically distinct microorganisms in each plate. The values were converted into colony-forming units per milliliter (c.f.u. $/ \mathrm{mL}$ ). To compare the means it was used the Tukey test at $5 \%$ probability.

\subsection{Effect of Organic Manure on the Mycelial Growth of P. parasitica}

To determine the effect of organic manure on growth of $P$. parasitica, the product obtained was filtered using gauze and added to the culture medium carrot agar (CA), at the following concentrations: $0,1.0,2.5,5.0,10.0$ and $20.0 \%$. After the preparation of culture medium, $16 \mathrm{~g} / \mathrm{L}$ of agar were added to the medium and then autoclaved for 20 minutes at $100 \mathrm{kPa}$. Subsequently, the medium were poured into Petri dishes. Discs of $5 \mathrm{~mm}$ diameter removed from a 7 days-old culture of $P$. parasitica (isolate IAC/95) were transferred to the center of the plates. Incubation of the cultures was carried out in a B.O.D incubator at $25^{\circ} \mathrm{C} \pm 2{ }^{\circ} \mathrm{C}$ in the dark. Determination of growth was realized when the colony of the pathogen in the control treatment reached the edge of the plate. The experimental design was a completely randomized set-up, with three replicates. The means were compared by Tukey's test $(P \leq 0.05)$.

\subsection{Effect of Organic Manure in the Control of P. parasitica in Different Citrus Rootstocks}

To evaluate the effect of organic manure in controlling the disease, Poncirus trifoliata cv Rubidoux (highly tolerant or resistant), Sunki mandarin (Citrus sunki Hort. Ex Tan) (susceptible), Rangpur lime (C. limonia Osbeck) (moderately resistant), Sour orange (C. aurantium) (highly tolerant or resistant) and Caipira sweet orange [C. sinensis (L.) Osbeck] (susceptible) plants were sprayed with the aqueous compound at concentrations equivalent to the treatments applied to the soil, for instance plants that have the organic manure incorporated into the soil at a concentration of $10 \%$ have leaves sprayed with organic manure in $10 \%$ of concentration, and so on. Inoculation with P. parasitica was carried out seven days after spraying (DAS) with the organic manure. This period was based on studies with eucalyptus (Eucalyptus spp.) in the control of rust (Puccinia psidii), according to Teixeira et al. (2005). Stems of Citrus plants were inoculated with a mycelial disk $(3 \mathrm{~mm})$ taken from a 7 days-old culture of P. parasitica (isolate IAC/95). Mycelial blocks were placed onto the center of a small cut made in plant stem. The inoculation site was protected with moistened cotton and parafilm. The plants were placed in an environment with a photoperiod of 16 hours at $25{ }^{\circ} \mathrm{C}$ and relative humidity (RH) of $85 \%$. This 
experiment consisted of four treatments: 1) plants that were only treated with organic manure (OM), 2) plants inoculated with $P$. parasitica (IP), 3) plants treated with organic manure and inoculated with $P$. parasitica $(\mathrm{OM}+$ IP) and 4) control plants, untreated with organic manure and non-inoculated. The evaluation was made by measuring the length of lesions in the inoculated stems, 60 days after inoculation of the pathogen. The experimental design was randomized blocks with four replications, with one plant per plot. The means were compared by Tukey's test $(P \leq 0.05)$.

\subsection{Analysis of Gene Expression}

In an attempt to elucidate the potential of the organic manure in the induction of resistance, we performed a study of gene expression using a reverse transcription quantitative real-time PCR (qPCR), in which levels of expression of genes encoding peroxidase $(P O X)$, lipoxygenase $(L O X), \beta$-1,3-glucanase, chitinase $(C H I)$ and chalcone synthase $(C H S)$, were evaluated in Poncirus trifoliata and Caipira sweet orange genotypes. As the plants were small, samples of leaves were collected from all parts of the plants of the treatment with 0 and $20 \%$ of organic manure concentration of the experiment carried out to evaluate the effect of biofertilizer in the control of $P$. parasitica in different Citrus rootstocks. The leaves were harvested 48 hours after inoculation with $P$. parasitica, flash-frozen in liquid nitrogen, and then stored at $-80{ }^{\circ} \mathrm{C}$ prior to RNA isolation. The choice of the genes and of the time to collect the leaves were based on previous studies focusing on the expression of local and systemic defense responses activated during the Citrus-Phytophthora interaction, detailed by Boava et al. (2011). The RNA extraction was performed using Trizol (Invitrogen Life Technologies), following the manufacturer's recommendations. After extraction, we proceeded to quantification in NanoDrop spectrophotometer ND - 1000 (Thermo Fischer Scientific, Massachusetts, USA). Then the treatment with RNase-free DNase I (Qiagen, Maryland, USA) was carried out at a concentration of $1 \mathrm{U}$ per 1,000 $\mathrm{ng}$ of RNA, to eliminate any contamination by DNA. The reaction was incubated for $30 \mathrm{~min}$ at $37^{\circ} \mathrm{C}$ and stopped by heat shock at $65{ }^{\circ} \mathrm{C}$ for $5 \mathrm{~min}$. The reverse transcription reactions (synthesis of cDNA first strand) were performed according to manufacturer's instructions of SuperScript First Strand Synthesis System (Invitrogen) with oligo (dT) primer (DT12-18, Invitrogen). Specific primers were designed based on their predicted function retrieved from Citrus Expressed Sequence Tags - CitEST database (http://biotecnologia.centrodecitricultura.br) (Table 1) using the Primer Express 2.0 software (Applied Biosystems) and synthesized by Integrated DNA Technologies (Prodimol Biotech A / S). The tests were conducted in the ABI Prism 7000 Sequence Detection System and 7500 Fast Real Time PCR System (Applied Biosystems, USA) by the system SYBR-green of detection (Wittwer, 1997).

Table 1. Oligonucleotide primers used for qPCR analysis

\begin{tabular}{|c|c|c|c|c|}
\hline & Description & CitEST & Forward/Reverse & Amp \\
\hline$P R 2$ & $\beta$-1,3-glucanases & CA-4000443 & $\begin{array}{l}\text { GCCGGCCTTGGAAACC/ } \\
\text { GCCGGCCTTGGAAACC }\end{array}$ & 97 \\
\hline$P R 3$ & Chitinase class I & CAS-CR-204551 & $\begin{array}{l}\text { ACAGAATTGTGGAAGCGG/ } \\
\text { AGCAAGTCTTCAAACATCTCC }\end{array}$ & 107 \\
\hline CHS & Chalcone synthase & CAS-CS-207154 & $\begin{array}{l}\text { AGTCTGAGGAAGCGAAA/ } \\
\text { CAAGCTTTGATGGGGACACT }\end{array}$ & 102 \\
\hline$L O X$ & Lipoxygenase & CAS-CS-111108 & $\begin{array}{l}\text { AATTCGACTTGGGTCTGTTC } \\
\text { CCGTAAGCGGATTGATAGG }\end{array}$ & 94 \\
\hline$P O X$ & Peroxidase & CAS-CR-201851 & $\begin{array}{l}\text { GATCTTCGTGCTCGTGTTCA } \\
\text { TGCGAATGTTTTGCTGTCTC }\end{array}$ & 96 \\
\hline$U B Q$ & Ubiquitin & CAS-PT-300961 & $\begin{array}{l}\text { TTCGTCAGTTGACTAATCCT/ } \\
\text { GTTGCTGTGTTGACTGTG }\end{array}$ & 95 \\
\hline$T U B$ & Tubulin & CAS-LT-602290 & $\begin{array}{l}\text { TTTGTAAGATCCCTCCGA/ } \\
\text { TCACCCTCCTGAACATTT }\end{array}$ & 87 \\
\hline
\end{tabular}

The expression levels were evaluated based on the number of PCR cycles required to reach a fixed threshold (threshold cycle - $\mathrm{Ct}$ ) in the exponential phase of PCR. Ct values were analyzed using version 4.3 .6 of the software Genex (http://www.multid.se/). For relative quantification, the method $2^{-\Delta \Delta C T}$ for the conditions for qPCR was applied (Livak \& Schmittgen, 2001). For plants treated with organic manure, plants inoculated with $P$. 
parasitica and plants treated with organic manure and inoculated, the levels of transcription of the genes were compared with the corresponding control (untreated plants with organic manure and non-inoculated), including Ubiquitin and $\beta$-tubulin gene as the endogenous control for reference. The standard deviations were used to show significant differences $(P<0.05)$.

\section{Results and Discussion}

\subsection{Determination of Microbial Community in the Organic Manure}

The results showed that the highest microbial populations was present in organic manure between 25 and 35 days after production, in which it was observed predominance of bacteria and Bacillus and a low total amount of fungi (Figure 1). These data are consistent with Kupper et al. (2006) which found that during fermentation, the fungus population is lower, whereas the total number of bacteria and Bacillus was significantly higher. However, it is believed that the total population of microorganisms in organic manure is higher than that indicated from plated samples.

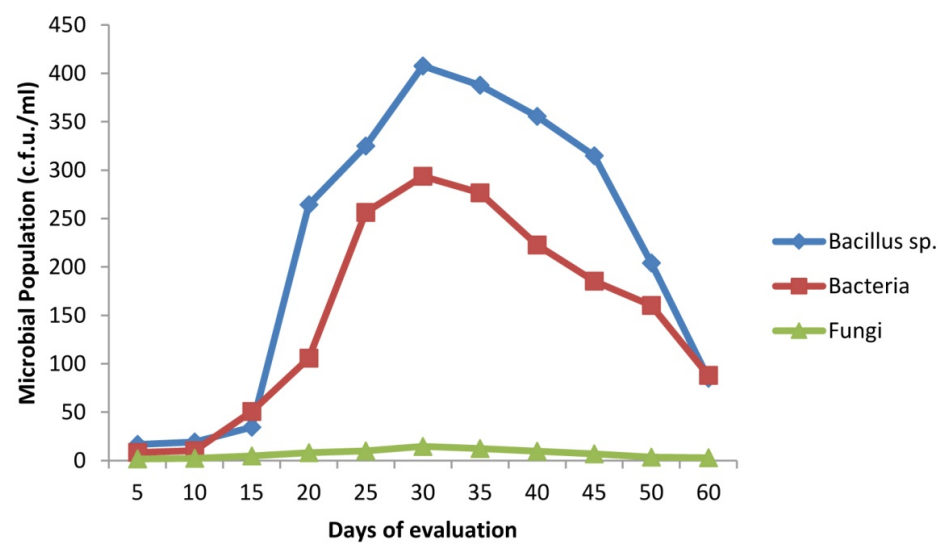

Figure 1. Microbial community present in the organic manure determined every five days for 60 days. Different culture media were used to count the total population of yeast, the number of bacterial colonies formed and the number of colonies of Bacillus spp. The values were converted to colony forming units per milliliter (c.f.u./mL)

\subsection{Effect of Organic Manure on the Mycelial Growth of P. parasitica}

The evaluations of the effect of organic manure showed that all concentrations affected significantly the mycelial growth of $P$. parasitica. But at concentrations of $20 \%$, the organic manure inhibited about $80 \%$ of the mycelial growth of the pathogen (Figure 2). It was observed that the colony diameter was inversely proportional to the organic manure concentration. For Kupper et al. (2006), concentrations higher than 10\% of biofertilizer, produced from anaerobic fermentation of cattle manure, caused a reduction in colony size of Phyllosticta citricarpa (teleomorph: Guignardia citricarpa) and the inhibition of the mycelial growth of pathogens was due the metabolites of the biofertilizer. Thus, it is believed that inhibition of colony growth of $P$. parasitica by organic manure was due to toxic metabolites (thermally stable) produced by microorganisms. 


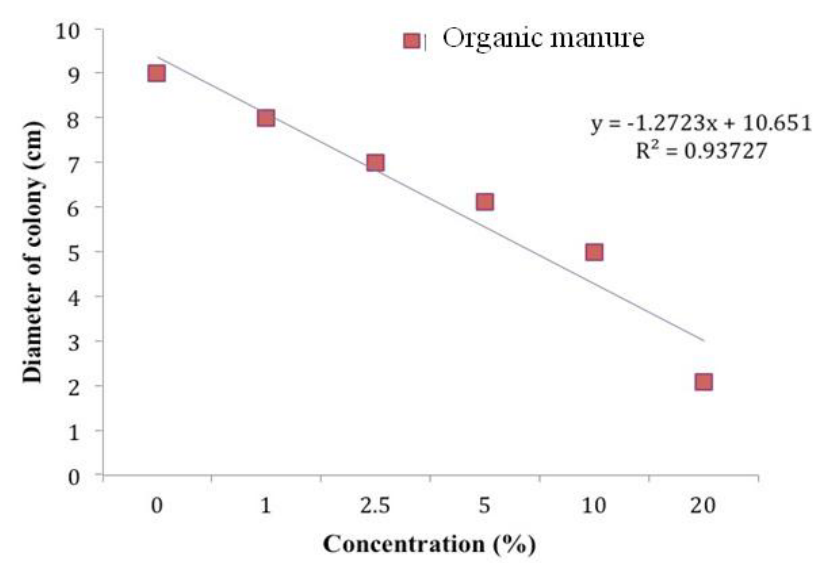

Figure 2. Effect of organic manure on Phytophthora parasitica colony diameter $(\mathrm{cm})$, the product obtained was filtered using gauze and added to the culture medium carrot agar (CA), at the following concentrations: $0,1.0$, $2.5,5.0,10.0$ and $20.0 \%$

\subsection{Effect of Organic Manure in the Control of P. parasitica in Different Citrus Rootstocks}

When the plants were inoculated with $P$. parasitica but not treated with organic manure the results showed that the susceptible genotypes Caipira sweet orange, Sunki mandarin and Rangpur lime had the highest average length lesions $2.43 \mathrm{~cm}, 2.25 \mathrm{~cm}$ and $1.96 \mathrm{~cm}$ respectively (Table 2). These results confirm that Poncirus trifoliata is highly resistant, the Sour orange as resistant, the Rangpur lime as moderately resistant and Caipira sweet orange and Sunki mandarin as susceptible (Alvarez et al., 2009). According Siviero et al. (2006), the lesions length is more suitable to characterize the rootstocks and new genotypes resistance to Phytophthora spp. when compared with measurements of the width of injury.

Table 2. Mean longitudinal length of the lesion $(\mathrm{cm})$ caused by Phytophthora parasitica, in five different genotypes of citrus rootstocks, Poncirus trifoliata cv Rubidoux Sunki mandarin (Citrus sunki Hort. Ex Tan) Rangpur lime (Citrus limonia Osbeck) Sour orange (Citrus aurantium) and Caipira sweet orange [C. sinensis (L.) Osbeck]

\begin{tabular}{lllll}
\hline \multirow{2}{*}{ Varieties } & \multicolumn{4}{c}{ Concentrations of organic manure (\%) } \\
\cline { 2 - 5 } & 0 & 10 & 20 & 50 \\
\hline Trifoliata & $0.91^{*} \mathrm{a} \mathrm{A}$ & $0,83 \mathrm{a} \mathrm{A}$ & $1.03 \mathrm{a} \mathrm{A}$ & $1.03 \mathrm{a} \mathrm{A}$ \\
Sour orange & $1.36 \mathrm{a} \mathrm{A}$ & $1.87 \mathrm{~b} \mathrm{~A}$ & $1.42 \mathrm{a} \mathrm{A}$ & $1.67 \mathrm{~b} \mathrm{~A}$ \\
Rangpur lime & $1.96 \mathrm{~b} \mathrm{~A}$ & $1.56 \mathrm{~b} \mathrm{~A}$ & $1.67 \mathrm{a} \mathrm{A}$ & $1.95 \mathrm{~b} \mathrm{~A}$ \\
Caipira sweet orange & $2,43 \mathrm{~b} \mathrm{~B}$ & $1.70 \mathrm{~b} \mathrm{~A}$ & $1.56 \mathrm{a} \mathrm{A}$ & $1.65 \mathrm{~b} \mathrm{~A}$ \\
Sunki mandarin & $2.25 \mathrm{~b} \mathrm{~B}$ & $1.90 \mathrm{~b} \mathrm{~A}$ & $1.98 \mathrm{a} \mathrm{A}$ & $1.81 \mathrm{~b} \mathrm{~A}$
\end{tabular}

Note. ${ }^{*}$ Means followed by the same letter, lowercase in columns and capital in rows, are not significantly different to according to the Tukey's test $(P \leq 0.05)$.

When the plants were treated with organic manure and inoculated with P. parasitica (Table 2), the susceptible genotypes Caipira sweet orange and Sunki mandarin expressed a decrease in lesion size at all concentrations of the organic manure tested, when compared to inoculated plants that were not treated with organic manure. This suggests that organic manure increases the resistance of susceptible rootstocks. However, at the concentration of $20 \%$, the lesion size among the genotypes did not differ significantly. McDonald et al. (2001) have also demonstrated the effect of biofertilizer in the increase of resistance of plants to pathogens.

\subsection{Analysis of Expression Gene}

Based on results of the effect of organic manure in the control of P. parasitica in different Citrus rootstocks we selected the genotypes Poncirus trifoliata (resistant) and Caipira sweet orange (susceptible) to verify if the resistance was associated with the induction of some selected genes. According to Hammerschmidt and Dann 
(1997), induced resistance can be activated as plant natural defences by certain types of infection or in response to treatment with biotic or abiotic agents.

The gene expression for pathogenesis-related genes, such as PR1 (function unknown), PR2 (b-1,3-endoglucanase), PR3 (chitinase class I), PR5 (Thaumatin-like protein), chalcone synthase (CHS), PAL, lipoxygenases $(L O X)$ and peroxidases $(P O X)$, was significantly higher in the resistant as compared to the susceptible interaction, as it was demonstrated by Boava et al. (2011) when they compared the expression of defense-related genes in $P$. trifoliata and $C$. sunki, resistant and susceptible, respectively, infected with $P$. parasitica. It is noteworthy, in this work that, all genes expression evaluated were significantly upregulated $(P \leq$ 0.05 ) in relation to the respective controls (non-inoculated and not treated with organic manure) in the susceptible genotype, Caipira sweet orange, after organic manure treatment followed by inoculation with $P$. parasitica suggesting that this combination was more effective to increase the resistance of Caipira sweet orange (Figure 3). According to Boava et al. (2009), metabolism alterations are more intense in an elicitor-induced plant challenged with a pathogen than in an only challenged or only induced plant suggesting that the former is more capable of responding to the presence of the pathogen.
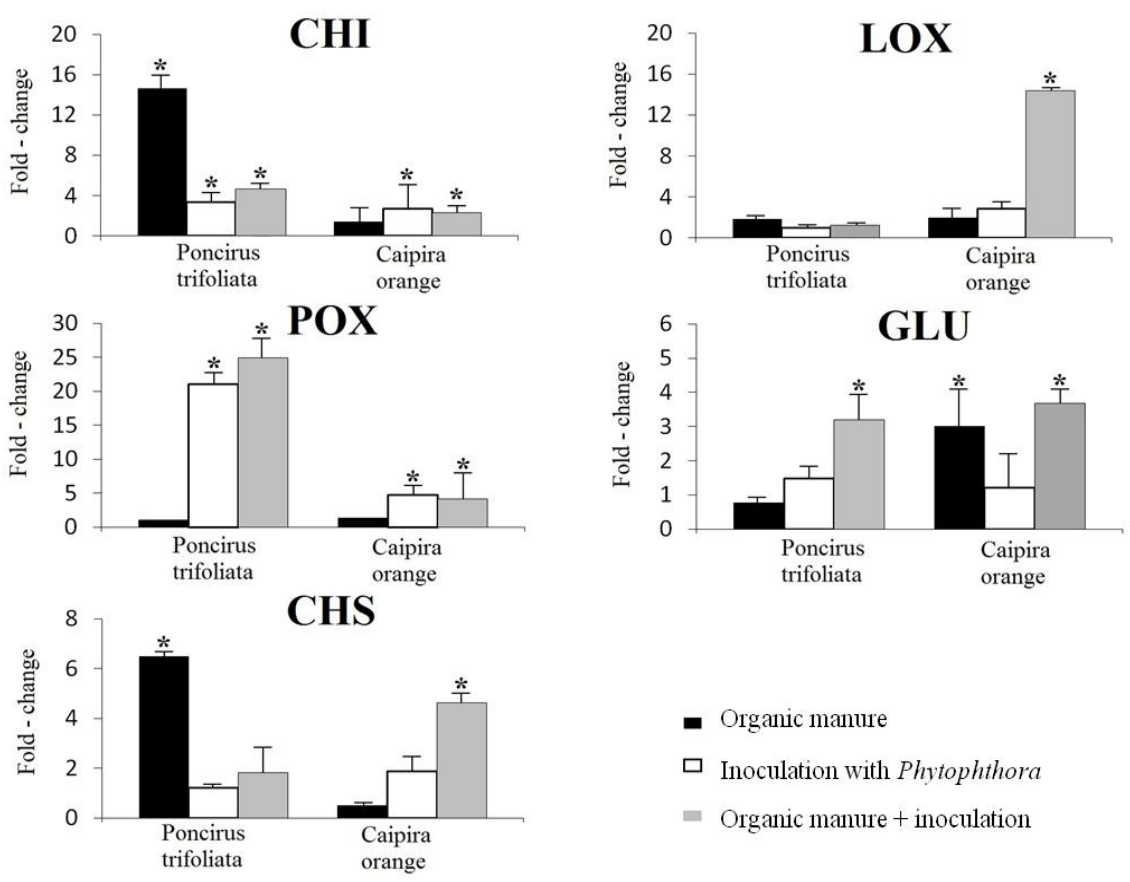

Figure 3. Expression pattern of defense and stress related genes in resistant $P$. trifoliata and susceptible Caipira sweet orange plants in response to effect of organic manure (at 20\%) and Phytophthora parasitica infection. Transcripts levels were represented as fold change in relation to non-inoculated control, including $\beta$-tubulin and

Ubiquitin as reference genes. Vertical bars represent standard deviations of the means of three replicates,

$*$ indicates that transcripts ratio was significantly (p-value $\leq 0.05$ ) greater than 2.0 -fold up or less than 0.5 -fold down in relation to non-inoculated controls. $C H I=$ chitinase; $L O X=$ lipoxygenase; $P O X=$ Peroxidase, $G L U=$ $\beta$-1,3-glucanase and $C H S=$ chalcone synthase

When the plants were treated only with the organic manure with no inoculation, $C H I$ and $C H S$ genes were highly expressed in $P$. trifoliata in relation to respective control, and $\beta-1,3$-glucanase gene was highly expressed in Caipira sweet orange in relation to respective control. Thus, we may suggest that it is possible that the expression of these genes can be triggered mainly in response to the organic manure, especially if one considers the presence of the microbial community in the compound. Nandakumar et al. (2001) induced resistance in rice by Pseudomonas fluorescens, a growth promoting rhizobacteria, and found a reduction in the severity of sheath rot caused by Rhizoctonia solani, correlated with an increase in chitinase $(\mathrm{CHI})$, which has antibacterial activity in reason of its lytic action on the cell wall and increased chalcone synthase $(\mathrm{CHS})$, which is key in the route of the biosynthesis of phenylpropanoids, such as phytoalexins and $\beta-1,3$-glucanase $(G L U)$, widely distributed in higher plants and induced during the hypersensitive response of plants to pathogens or some elicitors (Bucher et al., 
2001).

The results revealed that the gene $P O X$ was significantly upregulated $(P \leq 0.05)$ in Poncirus trifoliata and Caipira sweet orange in the treatments IP and OM + IP in relation to the respective controls (non-inoculated and not treated with organic manure) in both genotypes (Figure 3). Thus, we suggest that it is possible that expression of this gene can be triggered mainly in response to infection, and can be associated with enhance the resistance of the resistant genotype to infection by $P$. parasitica, since it is well documented that the susceptibility or resistance is not only determined by the presence or absence of resistance genes, but by the level of gene expression. Thus, it is believed that the smallest expression of $P O X$ gene in Caipira orange may not have been sufficient to contribute to the inhibition of colonization by $P$. parasitica, as noted by differences in lesion size between the genotypes $P$. trifoliata and Caipira sweet orange. This is in agreement with what was observed by Boava et al. (2011), where the expression of $P O X$ gene was significantly upregulated in resistant and susceptible plants at $48 \mathrm{~h}$ after $P$. parasitica inoculation. But in resistant plants the increase in gene expression was higher than in susceptible plants. According to Kawaoka et al. (2003) the peroxidase in plants includes several isoenzymes and isoforms. The catalytic reactions of peroxidase are diverse, and it plays an important role in plants. Aboshosha et al. (2008) found consistent results on the association of peroxidase with the resistance of plants. According to the authors, the peroxidase enzyme is one of the first to respond with increased activity as a specific reaction of resistance against plant pathogens. Previous studies suggest that peroxidase activity can lead to oxidation of different phenolic acids to antifungal compounds or direct inhibition of fungi. Thus, during the interaction between genotype and pathogen, peroxidase activity may not be produced at adequate quantities or on the correct time and site, which could justify the major severity of the disease affecting Caipira sweet orange, relative to $P$. trifoliata. This result also suggests that the induction of POX expression was most likely due to the effect of the inoculation of $P$. parasitica than the induction by the organic manure treatment.

When the plants were treated with the organic manure and followed by inoculation with $P$. parasitica (PI), in $P$. trifoliata CHI, $P O X$ and $\beta$-1,3-glucanase genes, were more expressed in relation to control plants and in Caipira sweet orange $C H I, L O X, P O X, C H S$ and $\beta$-1,3-glucanase genes were more expressed in relation to its control. Conrath (2009) related that the induced plants are sensitized and respond faster than the control. Aziz et al. (2003), observed an increase of chitinase and $\beta$-1,3-glucanase after the treatment of vine plants with a natural compound, thereby reducing the infection of Botryts cinerea and Plasmopara viticola in 55 and $75 \%$ respectively. It is noteworthy in this work that, the major changes in metabolism for $L O X$ in the susceptible genotype, Caipira sweet orange, occurred after organic manure treatment followed by inoculation with $P$. parasitica suggesting that this combination was more effective to increase the resistance of Caipira sweet orange. Boava et al. (2011) observed that the expression of $L O X$ in the resistant genotype occurred transiently in the early stages of pathogen infection, showing significant upregulation $(P \leq 0.05)$ at $24 \mathrm{~h}$ but not after $48 \mathrm{~h}$ post pathogen inoculation. However, the expression of $L O X$ in susceptible plants was significantly upregulated $(P \leq 0.05)$ at all stages for inoculated and wound plants treatments.

\section{Conclusions}

In the period between 25 and 35 days of production the organic manure had the highest microbial population and the analysis of gene expression suggested that the combination of organic manure treatment followed by inoculation with $P$. parasitica activated genes encoding chitinase, lipoxygenase, peroxidase, $\beta$-1,3-glucanase and chalcone synthase and it is believed that they can be involved with the resistance of Citrus plants to P. parasitica.

\section{References}

Aboshosha, S. S., Atta Alla, S. I., El-Korany, A. E., \& El-Argawy, E. (2008). Protein analysis and peroxidase isozymes as molecular markers for resistance and susceptibility of sunflower to Macrophomina phaseolina. International Journal of Agriculture and Biology, 10, 28-34. http://dx.doi.org/114/AKP/2008/10-1-28-34

Alvarez, L. A., Gramaje, D., Abad-Campos, P., \& García, J. J. (2009). Seasonal susceptibility of citrus scions to Phytophthora citrophthora and $P$. nicotianae and the influence of environmental and host-linked factors on infection development. European Journal of Plant Pathology, 124, 621-635. http://dx.doi.org/10.1007/s10658-009-9449-8

Aziz, A., Poinssot, B., Daire, X., Adrian, M., Lambert, B., Joubert, J. M., \& Pugin, A. (2003). Laminarin elicits defense responses in grapevine and induces protection against Botrytis cinerea and Plasmopora viticola. Molecular Plant-Microbe Interactions, 16, 1118-1128. http://dx.doi.org/10.1094/MPMI.2003.16.12.1118 
Boava, L. P., Cristofani-Yaly, M., Stuart, R. M., \& Machado, M. A. (2011). Expression of defense-related genes in response to mechanical wounding and Phytophthora parasitica infection in Poncirus trifoliata and Citrus sunki. Physiological and Molecular Plant Pathology, 77, 1-7. http://dx.doi.org/10.1016/j.pmpp.2011.07.004

Boava, L. P., Kuhn, K. J., Pascholati, S. F., Di Piero, R., \& Furtado, E. L. (2009). Effect of acibenzolar-S-methyl and Saccharomyces cerevisiae on the activation of Eucalyptus defences against rust. Australasian Plant Pathology, 38, 594-602. http://dx.doi.org/10.1071/AP09045

Bucher, M., Rausch, C., \& Daram, P. (2001). Molecular and biochemical mechanisms of phosphorus uptake into plants. Journal of Plant Nutrition and Soil Science, 164, $209-217$. http://dx.doi.org/10.1002/1522-2624(200104)

Conrath, U. (2009). Priming of Induced Plant Defense Responses (pp. 362-395). In Advances in Botanical Research (Ed.). Elsevier Ltda.

Hammerschmidt, H., \& Dann, E. K. (1992). Induced resistance to disease. In N. A. Rechcigl \& J. E. Rechcigl (Eds.), Environmentally Safe Approaches to Crop Disease Control (Vol. 8, pp. 177-199). Boca Raton: CRC Lewis Publishers.

Jiang, S., Park, P., \& Ishii, H. (2008). Ultrastructural study on acibenzolar-S-methyl induced scab resistance epidermal pectin layers of Japanese pear leaves. Phytopathology, 98, 585-591. http://dx.doi.org/10.1094/PHYTO-98-5-0585

Kawaoka, A., Matsunaga, E., Endo, S., Kondo, S., Yoshida, K., Shinmyo, A., \& Ebinuma, H. (2003). Ectopic Expression of a Horseradish Peroxidase Enhances Growth Rate and Increases Oxidative Stress Resistance in Hybrid Aspen. Plant Physiology, 132, 1177-1185. http://dx.doi.org/10.1104/pp.102.019794

Kupper, K. C., Bettiol, W., De Goes, A., Souza, P. S., \& Bellotte, J. A. M. (2006). Biofertilizer for control of Guignardia citricarpa, the causal agent of Citrus black spot. Crop Protection, 25, 569-573. http://dx.doi.org/10.1016/j.cropro.2005.09.002

Leoni, C., \& Ghini, R. (2006). Sewage sludge effect on management of Phytophthora nicotianae in Citrus. Crop Protection, 25, 10-22. http://dx.doi.org/10.1016/j.cropro.2005.03.004

Livak, K. J., \& Schmittgen, T. D. (2001). Analysis of relative gene expression data using real-time quantitative PCR and the 2- $\Delta \Delta C$ T method. Methods, 25, 402-408. http://dx.doi.org/10.1006/meth.2001.1262

McDonald, A. E., Grant, B. R., \& Plaxton, W. C. (2001). Phosphite (phosphorous acid): its relevance in the environment and agriculture and influence on plant phosphate starvation response. Journal Plant Nutrition, 24, 1505-1519. http://dx.doi.org/10.1081/PLN-100106017

Nandakumar, R., Babu, S., Viswanathan, R., Raguchander, T., \& Samiyappan, R. (2001). Induction of systemic resistance in rice against sheath blight disease by Pseudomonas fluorescens. Soil Biology \& Biochemistry, 33, 603-612. http://dx.doi.org/10.1016/S0038-0717(00)00202-9

Sinha, R. K., Valani, D., Chauhan, K., \& Agarwal, S. (2010). Embarking on a second green revolution for sustainable agriculture by vermiclture biotechnology using earthworms: Reviving the dreams of Sir Charles Darwin. Journal of Agricultural Biotechnology and Sustainable Development, 2(7), 113-128. http://dx.doi.org/10.5897/JABSD

Siviero, A., Cristofani, M., Furtado, E. L., Garcia, A. A. F., Coelho, A. S. G., \& Machado, M. A. (2006). Identification of QTLs associated with citrus resistance to Phytophthora gummosis. Journal of Applied Genetics, 47, 23-28. http://dx.doi.org/10.1007/BF03194595

Teixeira, D. A., Alfenas, A. C., Mafia, R. G., Maffia, L. A., \& Ferreira, E. M. (2005). Evidence of induction of systemic resistance to eucalyptus rust by plant growth promoting rhizobacteria. Fitopatologia Brasileira, 30, 350-356. http://dx.doi.org/10.1590/S0100-41582005000400003

Van Loon, L. C., Rep, M., \& Pieterse, C. M. J. (2006). Significance of inducible defense-related proteins in infected plants. Annual Review of Phytopathology, 44, 135-162. http://dx.doi.org/10.1146/annurev.phyto.44.070505.143425

Wittwer, C. T. (1997). The Light Cycler: A microvolume multisample fluorimeter with rapid temperature control. BioTechniques Natick, 22, 176-181. 


\section{Copyrights}

Copyright for this article is retained by the author(s), with first publication rights granted to the journal.

This is an open-access article distributed under the terms and conditions of the Creative Commons Attribution license (http://creativecommons.org/licenses/by/3.0/). 